Literature Review

\title{
Promising Male Hormonal Contraceptive are Well Established - Soon a Reality
}

Perkembangan Kontrasepsi Hormonal pada Lelaki - Segera Menjadi Kenyataan

\author{
Eka R Gunardi, Arnold Soetarso, Putri Addina \\ Department of Obstetrics and Gynecology \\ Faculty of Medicine University of Indonesia/ \\ Dr. Cipto Mangunkusumo Hospital \\ Jakarta
}

\begin{abstract}
Objective: To understand the modalities used for male hormonal contraception.

Methods: Literature review

Conclusion: Male contraceptive methods are still limited but hormonal contraceptive methods are being developed. The basic mechanism of male hormonal contraception is to inhibit spermatogenesis by suppression of the hypothalamic-pituitary-testicular axis function. Administration of testosterone or androgen derivative that is given in combination with progestin or $\mathrm{GnRH}$ antagonist shows that male hormonal contraceptive is reversible, effective, and acceptable as a male contraceptive method. However, no method of male hormonal contraceptive is ready for clinical use and marketed due to limited studies.

[Indones J Obstet Gynecol 2015; 3-4: 239-243]
\end{abstract}

Keywords: GnRH antagonist, male hormonal contraceptive, progestin, testosterone

\begin{abstract}
Abstrak
Tujuan: Untuk mengetahui modalitas yang dapat digunakan untuk kontrasepsi hormonal pria.

Metode: Kajian pustaka

Kesimpulan: Metode kontrasepsi pria masih terbatas, namun metode kontrasepsi hormonal masih terus dikembangkan hingga saat ini. Mekanisme dasar kontrasepsi hormonal pria adalah menghambat spermatogenesis dengan cara menekan fungsi dari aksis hipotalamushipofisis-testis. Pemberian kombinasi antara testosteron atau turunan androgen dikombinasikan dengan progestin atau antagonis GnRH menunjukkan bahwa metode kontrasepsi hormonal pria efektif, reversibel dan dapat diterima. Namun, saat ini belum ada kontrasepsi hormonal pria yang digunakan secara klinis dan dipasarkan oleh karena keterbatasan penelitian.
\end{abstract}

[Maj Obstet Ginekol Indones 2015; 3-4: 239-243]

Kata kunci: antagonis GnRH, kontrasepsi hormonal pria, progestin, testosteron

Correspondence: Eka R Gunardi. Department of Obstetrics and Gynecology, Faculty of Medicine University of Indonesia. Jakarta Telephone: 0816-933301. Email: eka_dhikita@yahoo.co.id

\section{INTRODUCTION}

Historically, family planning programs and studies have focused on women. Studies on male-involvement in family planning has increased contraception use. ${ }^{1}$ Male contraceptive methods are still limited, with condoms and vasectomy being the most widely used method. Condom use in men is ranked fourth globally but is often used incorrectly and inconsistently. Vasectomy is an effective and safe method but not favorable because it is not easily reversible. ${ }^{2,3}$ Therefore, there is a need for a new contraceptive method is effective, reversible, and acceptable.

Male hormonal contraceptive methods are constantly being developed. In theory, the male hormonal contraception works by providing negative feedback to suppress spermatogenesis. Gonadotropins from the pituitary will be suppressed by administration of testosterone or androgen derivative that is often given in combination with anti-gonadotrophic agent, such as progestin or GnRH antagonists. Methods of male hormonal contraception are one of the reversible contraceptive options with high effectiveness and will be discussed further below. ${ }^{4}$

\section{The Physiological Basis of Male Fertility}

There are 4 aspects that play a role in physiological basis of male fertility, which are:

\section{The hypothalamic-pituitary axis: control of go- nadotropin secretion ${ }^{3}$}

The hypothalamic-pituitary-testicular axis with negative feedback mechanism of the downstream products played the pivotal regulatory role in maintaining homeostasis. Hypothalamus will control pulsatile GnRH secretion, which regulates pituitary glands to 
produce gonadotropins (follicle stimulating hormone/FSH and luteinizing hormone/LH), whereas gonadotropins regulates testicular production of both hormones and sperm. Steroid and peptide hormone produced in the testes will provide a negative feedback signal to the pituitary and hypothalamus. Therefore, disruption of GnRH secretion is a potential target for contraceptive methods.

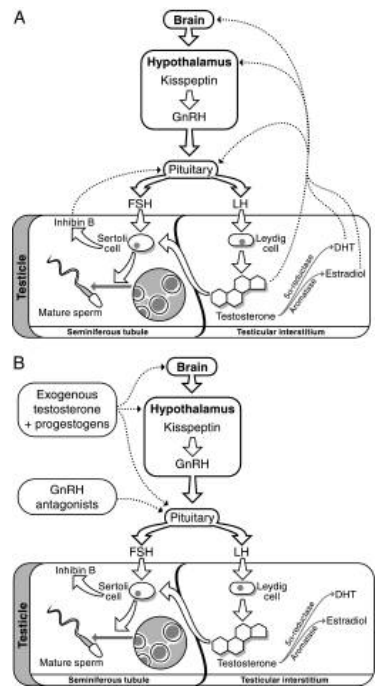

Figure 1. (A) Spermatogenesis in normal circumstances; (B) Effects of hormonal contraceptive intervention in the reproductive axis. Source: Page ST, Amory JK, Bremner WJ. Advances in male contraception. Endocrine reviews. 2008; 29(4): 465-93. PubMed PMID: 18436704. Pubmed Central PMCID: 2528850

Researchers found that the G protein receptor GPR 54 plays an important role in the secretion of gonadotropin and 54-amino acid peptide kisspeptin-54 (metastin) is the ligand for GPR 54. Subsequent investigations have demonstrated that kisspeptin administration in the brain results in GnRH and gonadotropin secretion in animal models and gonadotropin secretion can be blocked by administration of $\mathrm{GnRH}$ antagonists. Moreover, the negative feedback of testosterone and estradiol on GnRH secretion is mediated via inhibition of kisspeptin production in the arcuate nucleus of the hypothalamus. Inhibitors of kisspeptin, GPR 54 agonists and antagonists, in combination with testosterone in theory may be a strategy of contraception.

Testosterone is a steroid hormone produced primarly in the testes, but significant aromatase activity in the testicle and peripheral tissues result in production of estradiol as well. Testosterone works by inhibiting transcription of kisspeptin and GnRH and gonadotropin secretion. Estradiol also plays an important role in steroid negative feedback in men, par- ticularly by decreasing LH production. It is also known that FSH regulation is more dependent on estradiol compared to testosterone.

The precise role of progesterone in normal male physiology is unknown, but progesterone receptors have been demonstrated in the male hypothalamus, pituitary, and reproductive tract. Additionally progestin administration enhance male hormonal contraceptive efficacy when combined with androgens. The effect is attributed to increased hypothalamicpituitary suppression of gonadotropin secretion either directly or through the androgen receptor.

Finally, the nonsteroidal testicular product inhibin B contributes to hormonal feedback in males. Inhibin B is predominantly produced by Sertoli cells and will give negative feedback on the production of FSH. Theoretically, exogenous inhibin B in conjunction with androgens might further supress FSH, and can be used as a hormonal male contraceptive regimen.

\section{Testosterone production and androgen action ${ }^{3}$}

Testosterone is produced by the Leydig cells in the testes as a response to LH stimulation. However, studies in mice have shown evidence that testosterone production can also be non-LH dependent. Therefore, the regulation of testosterone production in non-dependent gonadotropin is a critical aspect in developing an effective male hormonal contraceptive method because hormonal contraception relies on blockade of gonadotropin secretion for efficacy.

In experiments, suppression of LH and FSH levels profoundly decreases testosterone production and reduces spermatogenesis in men. However, research on mice with LH-receptor-deficiency show that even with low androgen levels and further blockade of androgen receptor (flutamide) for complete suppression of residual androgen action, spermatogenesis can still occur, which will lead to contraceptive failure. Further investigation into the precise regulation and role of intratesticular androgens in supporting spermatogenesis in men is still needed, because targeted disruption of residual androgen production and action might be an adjunt to increase effectiveness of current hormonal methods.

Using a hormonal approach of contraception, testosterone is given to block gonadotropin secretion while maintaining nongonadal androgen-dependent functions such as sexual drive and muscle mass. Significant supraphysiological dosing of testosterone can 
be associated with side effects, which includes highdensity lipoprotein (HDL) suppression, acne, and increased hemoglobin concentrations that would not be desirable in a regimen designed or long-term use.

\section{Spermatogenesis ${ }^{3}$}

During spermatogenesis, spermatogonia will undergo 4 stages to develop into mature spermatozoa. First, type A spermatogonia undergo mitosis, resulting in renewal of germline stem cells as well as type B spermatogonia that continue to undergo differentiation. Secondly, type B spermatogonia undergo meiosis to become spermatids. Thirdly, there is spermiogenesis, where mature spermatids become motile spermatozoa. Fourth, the interaction with Sertoli cells mediate the spermiation process, where cytoplasmic material from the spermatid is removed and the mature sperm will be released into the lumen of the seminiferous tubules. This whole process requires regulation of endocrine hormones. FSH and LH are required for the above processes.

\section{Epididymis $^{3}$}

Once spermatogenesis has been completed, sperm are released from the Sertoli cells into the lumen of the seminiferous tubules, and move through the epididymis before ejaculation. FSH and testosterone are thought to play a role in spermiation and the release of spermatid into the tubule lumen. Failure of spermiation will lead to sperm retention and phagocytosis by the Sertoli cell. Within the epididymis, sperm undergo further maturation steps, allowing for maximal motility and fertilization capacity.

\section{Male Hormonal Contraceptive Mechanism}

The mechanism of male hormonal contraceptives is to inhibit spermatogenesis by suppression of the hypothalamic-pituitary-testicular axis function. A reversible azoospermic condition is targeted by this inhibition.

Hypothalamus secretes gonadotropin-releasing hormones $(\mathrm{GnRH})$ which stimulates the secretion of LH and FSH in the pituitary gland. LH binds to Leydig cells in the testicular interstitium and stimulates the production of testosterone. The resultant testosterone diffuses into the seminiferous tubules, and induces spermatogenesis, mediated by FSH stimulation from Sertoli cells. This Testosterone also enters the bloodstream and, in combination with estradiol, serves to regulate its own production by negative feedback at the level of the hypothalamus and pituitary gland. ${ }^{5}$

This regulation is used as a basic concept of male hormonal contraception. High level of exogenous testosterone will lead to inhibition of negative feedback regulation. It is accepted as a positive feedback in the hypothalamus and pituitary glands, so that the secretion of LH and FSH will be suppressed, as well as spermatogenesis. This regulation is expected to be reversible.

However, in several men, administration of testosterone alone fails to completely suppress sperm production. Therefore, ongoing study for combination male hormonal contraceptive still continues.

\section{Male Hormonal Contraceptive Studies}

Studies on male hormonal contraception have started since 1939. Testosterone administration is used to suppress secretion of LH and FSH from the pituitary. Low concentrations of these hormones will inhibit spermatogenesis and results in decreased sperm concentrations. First studies revealed reversible azoospermia in some patients with daily use of testosterone alone regimen administered in the duration of 60 days. Improvement of delivery frequency and dosage are still undergoing studies until now. However, some data have shown that administration of testosterone alone regimens fail to completely suppress spermatogenesis in many groups, due to ethnic differences, body fat content, baseline testosterone levels, different susceptibility of reductase levels for each groups and other reasons. The fact is, $91 \%$ of Asian and $60 \%$ of Caucasian patients become azoospermic due to differences in endocrine response. ${ }^{6}$

Recent studies still compared between administration of a testosterone-only regimen and testosterone combined with exogenous progestin.

\section{Androgen Only}

Testosterone-only administration has many side effects; including mood changes, weight gain, increase in hemoglobin and hematocrit, skin problems (oily skin and acne), decrease in testicular volume, gynecomastia, sleep apnea, and possible effects on cholesterol levels. ${ }^{6}$ 


\section{Testosterone Buciclate}

Testosterone Buciclate is a long acting testosterone derivative and have shown moderate effect of suppression of spermatogenesis at a dose of $1200 \mathrm{mg}$ per month given through intramuscular injection. The first study was conducted by World Health Organization (WHO) in 1995, and revealed minimal side effects. This trial helped in the initiation of another study combining long acting testosterone with progesterone derivatives.

\section{Testosterone Enanthate (TE) ${ }^{6,7}$}

The first study conducted by WHO applied a regimen of weekly intramuscular injections of $200 \mathrm{mg}$ Testosterone Enanthate (TE) for a year. As a result, $70 \%$ of the 271 patients became azoospermic within 6 months. The mean time needed for the process in the development of azoospermia was 3 months, and the mean time to recovery was 3-4 months. There was only one pregnancy occurring among the azoospermic patients who followed a 12 -month efficacy phase. However, $12 \%$ of the men discontinued from the study because of the discomfort caused by the weekly intramuscular injections and also administration of testosterone-only as a contraceptive purpose failed to suppress spermatogenesis.

Similar with the first testosterone study conducted by WHO, the second study found some difficulties with the administration of $200 \mathrm{mg}$ intramuscular TE for induction phase, and 100 mg weekly intramuscular injections in 399 volunteers. Although 98\% patient experienced suppressed spermatogenesis to below 3 million sperms per ml, but $25 \%$ of patients discontinued this study due to several reasons, which include weekly injection discomforts.

\section{Testosterone undecanoate (TU) 6,7}

A more recent multicenter study used a very-longacting formulation of testosterone undecanoate (TU), which can be administered once every 3-4 months for testosterone replacement in men with hypogonadism. In two large studies in China, 500 mg TU was used as a single contraceptive agent. The first study enrolled 308 healthy men, and their partners administered TU once a month for 12 months. During the study, 299 men showed oligospermia with sperm concentrations below 3-million sperm $/ \mathrm{ml}$ ejaculate, whereas nine men did not show suppression to this extent. As many as 296 of the subjects entered an efficacy phase, and six subsequently found it necessary to restart other forms of contraception because of their rising sperm counts. An overall efficacy rate of $95 \%$ was obtained from this study, with one pregnancy occurring in the study group. During the recovery period, hormonal levels and semen parameters returned to baseline.

A more recent study also carried out in China enrolled 1,045 men and their partners for a 1.5-year period using $500 \mathrm{mg}$ TU monthly dosage. As a result, this group showed a 95\% rate of spermatogenesis suppression and 95\% contraceptive efficacy rate. From both studies, TU seems to be a highly acceptable, effective, safe, and reversible method for male contraception in healthy fertile Chinese men.

\section{Synthetic Androgens}

\section{7 $\alpha$-methyl-19-norestrosterone (MENT)}

MENT is synthetic androgen with potent gonadotropin inhibitory activity and prostate sparing effects. ${ }^{8}$ This synthetic androgen is more potent than testosterone, it is resistant to $5 \alpha$-reduction, and has diffusion characteristics that make it easy to be administered in the form of depot implant. However, it has a similar side effect profile with testosterone and only provides partial dose-dependent suppression of spermatogenesis. Other sources have shown that MENT has a short half life, making it unsuitable for long-term injection; and that it does not show any significant FSH suppression. ${ }^{6}$

\section{Dimenthandrolone undecanoate}

Dimenthandrolone undecanoate is a potent synthetic androgen that has some progestational activity, which is currently in development for therapeutic uses in men. It appears to suppress LH secretion in vitro and in rabbit models. It works without stimulating prostate growth and is resistant to $5 \alpha$-reduction. ${ }^{9}$

\section{Combined with Progestin}

Combination of progestin and androgen replacement therapy as a contraceptive has been found to be well tolerated, safe, and effective. This method was known to be more effective in producing azoospermia at lower doses. 


\section{TU + Progestine}

Norethistrone enanthate $200 \mathrm{mg}$, a long-acting injectable progestin with weak androgenic and estrogenic activity, shows great promise as an adjunct agent in combination with TU (1000 mg) for male hormonal contraception. ${ }^{7}$ During a 6-months study in 40 men, comparing TU alone with TU + norethistrone enanthate, combination therapy was found to be more consistent in producing suppression of spermatogenesis and serum gonadotropins. ${ }^{10}$

In phase $2 \mathrm{~b}, \mathrm{WHO}$ conducted a contraceptive trial on 400 couples using TU and norethistrone enanthate injected once every 8 weeks for 48 weeks. This trial will provide additional data regarding the efficacy, safety, and tolerability of an injectable contraceptive regimen for men.

\section{$T E+$ Progestin}

An RCT of levonorgestrel and TE combination has shown that this combination was superior to TEonly in achieving azoospermia. Levonogestrel implants $(160 \mu \mathrm{g}$ daily) combined with TE injection, was known to be more effective than Levonogestrel (125 $\mu$ g daily) combined with testosterone patches. ${ }^{7}$ Injection of depot medroxyprogesterone acetate (DMPA) and TE also resulted in azoospermia in $98 \%$ of subjects.

\section{Combination with GnRH Antagonist ${ }^{3,4}$}

GnRH antagonist regimens have been shown to be more acceptable in suppressing spermatogenesis than GnRH agonist, when combined with androgen agents. GnRH antagonists can suppress FSH and LH production within hours of administration, and inhibit gonadotropin secretion more completely than agonists.

There have only been a few studies investigating GnRH antagonist Nal-Glu, administered by daily subcutaneous injections, combined with intramuscular TE resulting in an azoospermia rate of between $67 \%$ and $93 \%$ at 6 to 16 weeks of use. A more recent study reported that daily cetrorelix combined with 19-nortestosterone-hexyloxyphe-nylpropionate achieved azoospermia in $100 \%$ of subjects by 12 weeks. However, GnRH antagonists have the problem of needing daily subcutaneous administrations and being expensive.
Recently, a new long-acting GnRH antagonist (acyline) given at twice weekly intervals has shown promise in a small number of subjects producing an azoospermia rate of $67 \%$ at 8 weeks. However, there are problems with local injection site reactions including erythema and induration.

\section{CONCLUSION}

The development of an effective, reversible, and acceptable male hormonal contraceptive is possible. Until now, combination therapy of androgen and progestin has been shown to be more effective than the use of androgen-only regimens or GnRH antagonists. However, no male hormonal contraceptive is currently ready for clinical use, due to limited available studies.

\section{REFERENCES}

1. Levy J. Reaching the goals of Cairo: male-involvement in family planning. United States: University of North Carolina; 2006.

2. United Nations, Department of Economic and Social Affairs, Population Divison. World Contraceptive Use [Online]. 2009. Available from: URL: http://www.un.org/esa/population/publications/contraceptive2009/contracept2009_ wallchart_front.pdf

3. Page ST, Amory JK, Bremner WJ. Advances in male contraception. Endocrine Rev 2008; 29(4): 465-93.

4. Matthiesson KL, McLachlan RI. Male hormonal contraception: concept proven, product in sight? Hum Reprod Update. 2006; 12(4): 463-82.

5. Roth MY, Amory JK. Pharmacologic development of male hormonal contraceptive agents. Clin Pharmacol Therapeutics 2011; 89(1): 133-6.

6. Manetti GJ, Honig SC. Update on male hormonal contraception: is the vasectomy in jeopardy? Int J Impotence Res 2010; 22(3): 159-70.

7. Grimes DA, Lopez LM, Gallo MF, et al. Steroid hormones for contraception in men. Cochrane Database Syst Rev 2012; 3: CD004316.

8. Garcia-Becerra R, Ordaz-Rosado D, Noe G, et al. Comparison of 7alpha-methyl-19-nortestosterone effectiveness alone or combined with progestins on androgen receptor mediatedtransactivation. Reproduction 2012; 143(2): 211-9.

9. Attardi BJ, Hild SA, Reel JR. Dimethandrolone undecanoate: a new potent orally active androgen with progestational activity. Endocrinol 2006; 147(6): 3016-26.

10. Kamischke A, Venherm S, Ploger D, et al. Intramuscular testosterone undecanoate and norethisterone enanthate in a clinical trial for male contraception. J Clin Endocrinol Metabol 2001; 86(1): 303-9. 